\title{
HISTORY OF THE HUNGARIAN ECONOMIC TRAINING
}

\author{
Imola Cseh-Papp, ${ }^{1}$ Erika Varga, ${ }^{2}$ \\ ${ }^{1}$ Szent István University, Institute of Social Sciences and Teacher Training, Hungary \\ ${ }^{2}$ Szent István University, Faculty of Economics and Social Sciences, Hungary \\ papp.imoa@gtk.szie.hu, varga.erika@gtk.szie.hu
}

\section{Professional Paper \\ doi:10.5937/jouproman5-13507}

\begin{abstract}
Economics is a relatively young branch of science. It became an independent subject at the end of the 18th century. Taking the educational-political situation of the economic training into consideration the training was pushed to the periphery in the past centuries in the Carpathian Basin. Profound changes took place only with the Austro-Hungarian Compromise of 1867 when the state paid more attention to improving he most disadvantaged regions, which resulted in giving a new impetus to industrial development. Our paper makes an attempt to summarize the history of the economic training in the Carpathian Basin. Without giving all the details it tries to take account of the events (of the fight for an independent university of economics) from the beginnings through the history of Collegium Scientiarum Politico Oeconomico Cameralium, the events of the University of Nagyszombat, the foundation of József (Joseph) Technical School and the history of József nádor (Palatine Joseph) University of Technology and Economic Sciences to the foundation of the first Marxist university and later the introduction of the Bologna system.
\end{abstract}

Keywords: economic training, history, education, courses, study programmes

\section{Roots of professional education}

Organized technical training was first carried out by the guilds that appeared in Hungary simultaneously with the development of the industry and city life at the beginning of the 14th century. For long the guild certificate of the skinners of Kassa (Kosice) was regarded as the first Hungarian one who received it in 1307. However, its authenticity was questioned and there were also some issues of content raised. What is for sure is that the Saxon code in Transylvania issued by Lajos Nagy (Louis the Great) in 1376 on 24 trades meets the guild requirements. It regulated taking on apprentices, assisting the members who were unemployed, unable to work or too old, taking care of widows, orphans and paid the last respect to the deceased as a union. Furthermore, it also checked qualifications and protected quality by examining goods very closely. Till the 16th century apprentices were not required to have any previous qualification or schools but later reading and writing skills were demanded.

While we are looking for the roots of professional education we have to note that it was typical of the guilds that the apprentice moved to live with the master. They were not given salary; instead, they received food, shelter and scarcely clothes. The working hours were practically unlimited, from dawn till dusk. If the apprentice succeeded in completing their study, a letter of recommendation as a student could be applied for. As young lads, they typically stayed with the master for one or two more years, for only half the standard salary at first. During this period they were preparing to move away with the original purpose of getting to know the industrial techniques of other foreign cities and workshops. Guild codes also fixed the duration of wandering (2-5 years). 
Afterwards, the apprentice obtained the right to become a master with a masterpiece.

The first signs of technical training at schools can be found at the city schools of German, Latin and then Hungarian institutions, where teaching predominantly took place in the mother tongue.

\section{The beginning of commercial and economic training}

In line with the educational policy of the enlightened absolutism (despotism) of the second half of the $18^{\text {th }}$ century in the east part of the Habsburg Empire including Hungary the process leading to the establishment of different technical schools of higher education ${ }^{1}$ had started by the end of the century. These measures were not made later than in the west part of the empire; rather, they commenced simultaneously.

The miner officer training institute of Selmecbánya began to develop into an academy in 1793 and as a result of this process by 1770 one of the most modern institutions of the period was run in the old mining town.

At the same time, Maria Theresa founded a school of accounting named Collegium Scientiarum Politico Oeconomico Cameralium in Szenc, Pozsony (Bratislava) county in 1763 directed by the piarist Jakab Valeró. In 1763 the school was inaugurated. The importance of economic sciences was lying in the exploitation of the natural treasures of Earth. The school in Szenc went on operating till 1776 when it was burnt down.

The college can be regarded as the antecedent of all kinds of technical

\footnotetext{
${ }^{1}$ Fináczy Ernő: A gazdasági felsőbb szakoktatás kezdetei Mária Terézia alatt, Magyar Gazdaságtörténeti Szemle, 1899/6 , 199-204

trainings in higher education in Hungary as it used to function as a 'college' training engineers, running agricultural courses and functioning as a cameral-economic technical school. This institution lasting for three years with 5 professors teaching in German represented a rather short but significant episode in the history of the technical higher education in Hungary.

Again, owing to the grace of Marie Theresa a drawing school (Scola graphidis) was established in Buda in 1770 following the pattern of similar institutions abroad ${ }^{2}$. It might have served as an example when establishing 'Sunday schools' in all big cities in accordance with Ratio Educationis (1777) where classes took place once a week on Sunday afternoons from $2 \mathrm{pm}$ and primarily writing, reading and counting were taught. In 1783 Joseph II made the attendance of the Sunday drawing schools compulsory for apprentices. The most famous of these schools was operating in Györ which was partly embourgeoised. The school's flourishing can be connected to Miklós Révai (1749-1807). The drawing school of Körmöcbánya founded in 1787 can also be regarded as one of the famous schools of the era. In addition, a very precious initiative at that time was taken by Sámuel Tessedik who founded the Practical Economic and Technical School operating from 1780 to 1806 only with a short intermission together with the grammar school of Count György in Csurgó.

In the spirit of mercantilism of the era Ratio Educationis assigned great significance to trade. ${ }^{3}$

\footnotetext{
2 Mészáros István: Magyar iskola: 996-1996. Eötvös József Könyvkiadó, Budapest, 1996, 297

${ }^{3}$ Fináczy Ernő: A gazdasági felsőbb szakoktatás kezdetei Mária Terézia alatt, Magyar Gazdaságtörténeti Szemle, 1899/6., 199-204
} 
Teaching economic and cameral subjects did not stop in Hungary after the disintegration of the college in Szenc; rather, the subjects taught there were transferred to the classrooms of more renowned national institutions. However, Cameralistics was indispensable for the officers of the period not only in public administration or at the Chamber so transforming it into a subject at the only Hungarian university of sciences and later the so-called academies of the district was thought to be very important by the leaders of enlightened absolutism. In this sense economic training was raised to a higher level when the Court organized a new department called Studium politicocamerale at the Faculty of Arts in Nagyszombat in 1769 . For 81 years, i.e. till 1849 the political-cameralistic subjects had a separate department at the only Hungarian university. First from 1769 to 1777 the department was run by the Faculty of Arts, then from 1777 by the Faculty of Law, which can be regarded as the department of public administration, finance, economics, trade and bill of exchange law. Similar subjects were taught at the law courses of the academies in the districts after 1777 .

At the beginning of the $19^{\text {th }}$ century almost all the science subjects were assigned to independent schools even if they were of different standards. The situation of teaching economics and trade was different, though. These subjects were not taught at independent colleges till the mid-19th century and later on they were integrated into other institutions to reach the university level. The reason for this is evident deriving from our disadvantaged economic relations, but this could serve as a reason in many other cases. The wealthy orders, especially the affluent landowners of Hungary were primarily interested in developing agriculture and it is not by accident that the initiatives by the magnates were taken in training agricultural experts. The central offices of the state were interested in building infrastructure, road networks, sewage systems, regulating rivers etc. of acceptable standard in the country lagging behind so the training of engineers indispensable for these purposes was preferred. The Court was not at all or only partially interested in developing national trade as Hungary was regarded as the market outlet of the developed provinces.

Ratio Educationis II of 1806 brought along rather negative features from the aspect of educating law and cameralistics was one of the subjects that were taught at both academies and universities so it did not have a special university characteristic.

\section{The foundation of József (Joseph) Technical School}

The reform era of our history can be dated between the National Assembly of 1825 and the last parliamentary meeting of 1848 . The idea of the period was economic development based on technical training ${ }^{4}$, Maybe the first work of such nature belongs ot András Fáy (1786-1864) entitled "Próbatétel a mai nevelés két nevezetes hibáiról' (Probing two peculiar mistakes of contemporary education) published in 1816 in which he supported the development of technical training. Count István Széchenyi stated in his Stádium (1833) that industry and trade required rigid calculations, knowledge and capital with respect. At that time the question of establishing a technical school of everyday teaching was raised with its foundations lying in the Sunday school.

\footnotetext{
4 Pukánszky Béla - Németh András: Neveléstörténet, Nemzeti Tankönyvkiadó, Budapest, 1996, 167
} 
Emanuel Gyula Bibanco with his support to the Pest Civil Trade Organisation in 1830 founded a trade school on everyday basis. The institution was a one-year long elementary level trade school with a preparatory class. However, it was the Bibanco School that can be regarded as the first national initiative that served as an example for the trade schools of other cities and also prepared the ground for raising the teaching of trade and economics to a higher level. The institution earned the title of public trade school in $1838 .^{5}$

After heated county debates the plans on developing the economic life and trade of Hungary were discussed by the assembly of 1832-36. In the last days of the National Assembly in April 1836 the orders asked the emperor to permit the establishment of Polytechnics following the pattern of the engineering institute of Vienna. ${ }^{6}$ The plans of establishing polytechnics also marked the beginning of economic training in higher education as the institute followed the model of the Polytechnics in Vienna. A decision on the foundation of a technical school was made in the summer of 1844 and following the initiatives of the assemblies of the reform era the Joseph Technical School, bearing the name of the palatinus, was opened in 1846. The training lasted for three years and after a preparatory year two years of studying economics, engineering or trade followed. The school can be by all means regarded as the beginning of the economic training pointing towards higher education. The Hungarian language was used in

\footnotetext{
${ }^{5}$ Schack Béla - Vincze Frigyes: A kereskedelmi oktatásügy fejlődése és mai állapota Magyarországon, Budapest, Franklin Társulat, 1930, 448

${ }^{6}$ Schack Béla - Vincze Frigyes: A kereskedelmi oktatásügy fejlődése és mai állapota Magyarországon, Budapest, Franklin Társulat, 1930, 448
}

teaching but German was a compulsory subject.

\section{The economic education of the} era of absolutism and dualism

The teaching staff of the Technical School worked out the plan how to reform the Hungarian technical and commercial higher education thoroughly. The main task of the would-be Technical Academy was to help the domestic merchants with nationalization. After the fall of Hungary's freedom fight strict disciplines were made for the teachers of the Technical School like those of the university. With the exception of two teachers all old staff members and the director were made redundant or retired. ${ }^{7}$

No words could be spoken about implementing the previous great reform plans. Instead, the head of the public education in Vienna, Count Leopold von Thun wanted to tailor Hungary's educational policy to that of the empire. As a first step, on 29 September 1850 the emperor ordered the unification of the Institutum Geometricum of the Faculty of Arts of the university with the Joseph Technical School. The statute catered for the necessity of establishing a higher education institution similar to the other technical institutions of the empire based on the two organizations. From 1850 to 1857 only the state-owned secondary K. K. Josephs Industrieschule represented teaching technical and commercial subjects. After catering for the placement of the institution the Ministry of Religion and Public Education of the empire moved the Technical School to the Castle of Buda in the summer of 1854 and it conducted negotiations about the three-year old recommendations of transforming the Technical School.

\footnotetext{
7 Szögi László - Zsidi Vilmos: Tanulmányok a magyarországi közgazdasági felsőoktatás történetéből, Budapest, 1995, 204
} 
Thun modified the plans in line with his own ideas. The name of the new institution of Buda became K. K. Josephs Polytechnics. Franz Joseph approved Thun's proposals on 30 September 1856 as well as the new code of the Technical University. In the Polytechnics a class of economics was also formed so economic subjects were continuously taught at the Technical University. The Institution started to use the name Joseph Technical School from 1861. The technical, specialized system, which was the antecedent of the would-be faculties, was introduced in 1863.

After the Austro-Hungarian Compromise of 1867 it became obvious that the University of Technology could primarily engage in teaching mechanical and technical subjects. After 1867 the name of the independent economic class disappeared from the programs but the system of education did not change until 1871. On 1 November 1857 Pester Handels-Akademie was opened, which was the first trade school of higher education. Later on the name was changed for Budapest Trade Academy and it primarily catered for the secondary education in its modern sense. Lack of knowledgeable trade experts became an increasingly acute problem for the economically developing Hungary in the 1880's. The objective of the meeting summoned by Ágost Trefort, Minister of Religion and Public Education in January 1883 was to teach Eastern languages to the applicants for the course. All this in a way so that merchants travelling across the neighbouring countries, i.e. Serbia, Romania, Bulgaria, Turkey and Greece should get acquainted with the conditions of production for both industrial products and raw materials, be informed about export and import, and use all this in our commerce and trade. A committee of the Budapest Trade Academy worked out the plan of the Eastern Trade
Course primarily supported by Gábor Baross, Minister of Trade but after all, it was not opposed by Count Albin Csáky, the Minister of Public Education, either. The Eastern Trade Course proved to be a success even in its first year of operation. ${ }^{8}$

The director of the independent college-level Eastern Trade Academy became the Turkish scientist, Ignác Kunos. The objective of the Academy was to train experts in trade and foreign affairs of the trade and politics directed towards the Balkan and the Middle-East. From 1900 the higher education section of the Budapest Trade Academy lasted for two years. In 1902 the Trade Academy of Kolozsvár (Cluj Napoca) was founded followed by the foundation of the Export Academy of Fiume (Rijeka) in 1912. Till World War I altogether 3493 students gained their certificates at the higher education section of the Budapest Trade Academy. ${ }^{9}$

\section{Fight for the independent university of economics}

Elemér Balogh CEO of Hangya (Ant) Cooperative urged by Count Sándor Károlyi on the Kassa (Kosice) Congress of the Hungarian Farmers' Cooperative in 1900 proposed the foundation of a university of economics that could also include the education of agricultural, forestry and veterinary disciplines in addition to economics according to the concept of that era. Because in the meantime teaching forestry and veterinary sciences was raised to a college level, the two remaining problematic areas of Hungarian higher education without university-level education were agriculture and economics until the 1910's.

\footnotetext{
8 Szögi László - Zsidi Vilmos: Tanulmányok a magyarországi közgazdasági felsőoktatás történetéböl, Budapest, 1995, 204

9 Szögi László - Zsidi Vilmos: Tanulmányok a magyarországi közgazdasági felsőoktatás történetéből, Budapest, 1995, 204
} 
There was a plan for a four-faculty university which is a higher education institution for agriculture also with technical and trade-finance faculties. At the fourth faculty teaching sociology and social sciences was proposed with the necessary political, legal and economic knowledge as well as the most important Western and Eastern languages.

On 19 December 19 on the 317th national assembly meeting Count Mihály Károlyi put forward his plan for establishing an independent university of economics. Of course, his plan received negative criticism. The chair of OMKE (National Hungarian Trade Association) Pál Sándor asked for permission to speak on the 7 June meeting before discussing the agenda. He asked for adjourning the meeting due to the parliamentary excitement, which was accepted 'We were talking at cross purposes'- Elemér Balogh wrote in his memoirs, 'at the moment I thought I had reached the objective.' 10

There was a roundabout in the fight for an independent economic university. On its 21 June 1912 meeting, the board of the technical university proposed the foundation of an independent economic division to serve the purpose of further educating qualified engineers. This solution seemed to be much simpler and cheaper than establishing a new, independent university of economics.

The issue of economic training at university level gained impetus in 1918 when again János Zichy was appointed for the post of minister of culture. On 23 July the minister sent a long rescript to the University of Sciences in Budapest outlining his ideas and asking for the opinion of the four faculties to start

\footnotetext{
10 Szögi László - Zsidi Vilmos: Tanulmányok a magyarországi közgazdasági felsőoktatás történetéböl, Budapest, 1995, 204
}

university level economic training as soon as possible. All the four faculties responded in the first half of August with a style and content characterized by 'but...' On 10 October 1918 the committee consisting of the representatives of agriculture as well as political and scientific life could work out the text of the royal ordnance and after having gained the approval of the council of ministers, it was forwarded to the emperor. Charles IV gave his royal consent on his way to Debrecen in a carriage of the train. The papers were presented to the cabinet office on 29 October but due to the disintegration of the Monarchy they were never returned.

Finally, the opening of the academic year ceremony of the faculty of economics took place on 31 October 1920 in the ceremonial hall of the Hungarian Academy of Sciences. After a short introduction by Milks Horthy, Count Pál Teleki prime minister and the dean, István Bernát delivered their speech.

After the forced peace treaty of Trianon the cornerstone of Klebersberg's policy was that education, culture and higher equation are strategic issues and the weak country should use all its power to show the world how elaborate the Hungarians are and present a higher standard of culture than the neighbouring countries. The Treaty of Trianon strictly limited the amount of money spent on military issues so in real there was more money on higher education in the 1920's than it could be expected from a country weakened and bled in the war. This significant amount was spent on two purposes in higher education and research. One of them was student scholarship policy and developing foreign cultural relations. Klebelsberg was consciously devoted to widen the international scientific relations of the country. 
After 1920 the network of Collegium Hungaricum was opened and developed in Vienna, Berlin and Rome but a research institute or a department of Hungarian was formed at every significant university of all the countries of Europe. The National Scholarship Council was backed and almost every talented young person could spend 1-2 semesters abroad to lay their scientific research work on solid foundations. Mainly the people of humanities went to Vienna, the natural science researchers headed for Berlin while art lovers and the representatives of the church travelled to study in Rome. Changes were reflected by the fact that more and more students made their way to French, English or American universities supported by the state or by private foundations such as Rockefeller or Jeremy Smith. 'The Hungarian higher education and science made a profit from the intellectual capital piled up by the Hungarian researchers, teachers and scientists trained abroad and in the country for long decades after 1945. ${ }^{11}$

\section{Palatine Joseph's University of} Technology and Economic Sciences. The fight for establishing an independent economic university

After long, heated debates on Act X of 1934 a new university with peculiar size and structure was founded termed as Hungarian Royal Palatine Joseph University of Technology and Economic Sciences. The former technical university of Budapest formed the base of this new institution by attaching almost all institutions that were dealing with sciences at university or college level.

The organization of Palatine Joseph University of Technology and Economic Sciences disintegrated following World
War II. In 1945 agricultural divisions became independent and afterwards the issue of establishing an independent university of economics was raised while reorganizing higher education in a Marxist spirit.

Reforms were demanded from 1945. The academic year of 1946/47 and the next one were devoted to reform meetings. The passage of time demanded an evening course at university level from 1946/47. The first great university reform was launched in 1948 with the objective of developing technical and economic trainings in line with the socialist planned economy advocating the priority of industrial development.

Government Decree 9160/1948 (25 September 1948) ratified by Act LVII of 1948 (28 December 1948) ensured the establishment of a truly independent Hungarian University of Economics. The new university could hardly be termed as the legal successor of the economic faculty of the university of sciences or the Faculty of Economics of Palatine Joseph University of Technology and Economic Sciences. All the old professors were sent away, departments were reorganized, the subjects were changed together with the system of education and the economic training stopped. Students were selected after passing an entrance exam, which was strongly influenced by politics. What is more, by 1950/51 even the place of the university was altered: it moved from Szerb Street to Fővám square. The institution was directed by economists returning from or studying in the Soviet Union after the old steachng staff had been made redundant. The first Marxist university of Hungary was born ...

11 Győriványi Sándor: Fejezetek a magyar szakképzés történetéből, Új Pedagógiai Szemle, 1996/10 sz., 94-105 


\section{Economic training after 1948}

In 1953 on the basis of Statute 3 it changed its name to Charles Marx and was wearing it till 1990 when the name was changed to University of Economics, Budapest.

There was an entrance exam from the beginning even for those who started their studies at the old university. The families as well as the political influence of the students applying had a great significance during the exam. The teaching staff was also transformed to a great extent and teachers also came from the Soviet Union. The materials taught were characterized by transferring the Soviet practices in education in addition to the classics of Marxism-Leninism. In 1948 an evening course was also started with the undergraduate one while the correspondence course started in 1951.

The university was run with only one faculty at the beginning, and specializations appeared in 1950. In 1952 correspondence courses were formed for the industry, commerce, political economics and finance. In the evening or correspondence course the common first year was handled separately before the specializations. The organization of the faculty - General Faculty of Economics, Industry and Commerce - was created in 1955. In 1957 the engineer-economist training started for the qualified engineers while in the industry and foreign trade program the Further Education Institute of Economics was formed to organize postgraduate courses.

In the country several cities had courses (Debrecen, Szeged, Miskolc, Pécs) of which the one in Pécs became the Faculty of Economics of the Janus Pannonius University of Sciences in Pécs while the other one in Miskolc became the Faculty of Economic Sciences. The organization of the university changed significantly a lot in the past few decades. The new curriculum tailoring the principles, content and structure of the training to the current one was introduced in 1988 in the first year. In the academic year 1990/91 the modernization of education stepped onto another stage. Starting from 1992/93 the training had two parts: after three years all students receive a college degree. The second phase qualifies students as economists at a university level. This was on at the economic, management and general social sciences faculty in the study programs of economics, management, international relations, political sciences, sociology and social politology. Different faculties serve the bachelor and postgraduate economic training.

\section{The development of a university-level economic training}

The Hungarian University of Economics established in 1948 continued its operation under the name Charles Marx University of Economics from 1953. At that time the Marxist-Leninist materials were extended. Within a short period excessive specialization became typical whose faultiness is justified by the fact that even the Council of Ministers ordered its disintegration in 1956. At that time economic experts were mostly expected to maintain planned economy, which was reflected by the fact that the necessary practice and theory were taught in the economic training.

During this period teaching political economics played a significant role. The organizational framework of direct ideological education was constructed in the academic year 1949/50. The Central Department of Marxism-Leninism of the Budapest University of Sciences was responsible for teaching Marxism in all the higher education institutions of the country. 
In the centralized, planned economic system economists were primarily employed by the central governing bodies, the National Planning Office and Price Office as well as the economic units of foreign trade companies, i.e. state-owned companies, state-owned farms and cooperatives The economic work became administrative and a lot of employers were not qualified for the economic job they were doing. There was a growing need not only for independent economic training but also the economic knowledge of technical and agricultural experts had to be broadened so that they could to perform their duties in different economic fields. This led to the introduction of new courses such as that of agricultural economists. To train these experts, the Council of Ministers established the Faculty of Agricultural Economics at the Gödöllö University of Agriculture in 1951.

The training system of the era was tailored to the all-time needs of the economy so great universities often modified their training system several times. The economic reform of 1968 brought along a great change in the educational system. The new economic mechanism had substantial impacts on the economic works, which called for a new type of economists. In contrast with the previous traditions, a brand new market approach came to the foreground, which, of course, required market-oriented experts. Therefore decision-making preparatory and analysing tasks were given a greater emphasis and functional areas that had been pushed into the background previously came to the foreground such as market research, trade, management and business administration. Consequently, the need for the economist with new knowledge was growing.

The content and the subjects of the economic training started to be transformed. New subjects were introduced such as organizational theory and sociology. The impact of market orientation on education induced another change, as well: practice became more important and by organizing seminars and factory visits the proportion of theory and practice also changed. The study programs of macro, national economic and micro enterprises also appeared.

Due to the economic needs of the socialist planned economy the economic training was given a separate faculty at several great universities of the county. In September 1970 the Pécs Division of FullTime Students of Charles Marx University of Economics started its operation. So the Pécs faculty became the second oldest and the first non-Budapest-based economic faculty in Hungary, and in its latter function, it served as a role model for the faculties of economic sciences established later in the countryside.

After the initiatives in Pécs, the Faculty of Economics of Miskolc University opened its doors in September 1987. The Technical University of Heavy Industry, as it was called then, was given the permission to launch a college level economic training on the basis of the Regulation of the Council of Ministers 37/1986. (31 August). In the same year the so-called Faculty of Social Sciences, later becoming the Faculty of Economics and Social Sciences was also founded.

\section{Economic training after the change of the economic-social regime}

The regime change of 1990 resulted in continuously transforming the economy, which called for another type of approach and economic way of thinking, which brought along some changes in the training and educational system from the 1990's. First, it became apparent in the knowledge imparted. 
The training systems abroad could not entirely be copied owing to the transforming economic, educational and research environment. The two-tier (level) system in education was evolving.

There was a standardized entrance exam system but it was possible to graduate after 3 years, which resulted in a college degree.

Afterwards, economic trainings were started at the great universities of the countryside. In Györ, at the forerunner of the present-day Széchenyi István University educating business economists started in September 1990 followed by training economists in 1992 at the college of economics. In Debrecen, the regional center of the North Great Plains training economists was launched at the former Lajos Kossuth University of Sciences in 1993. Significant monetary and professional assistance was provided by the World Bank, the FEFA application containing the support of the Hungarian government and the three TEMPUS grant of EU funds in establishing and developing the economic training.

It is necessary to mention as a background to the economist training of Szeged that in 1921 the Franz Joseph University of Sciences moved from Kolozsvár (Cluj Napoca) to Szeged but the economist training in Szeged did not start until 1994, after 73 years. The forerunner of the University of Sopron is the Mine Officer School in Selmecbánya founded by Charles III in 1735 and transformed into an academy in 1762 by Marie Theresa. The institution was housed in Sopron in 1919 under the name Hungarian Royal College of Mining and Forestry where the economist training was launched in 1995 in the form of a correspondence course. The first undergraduate students started their academic year in September 1996 in the study program of management, which was licensed for the university and from the autumn of 1998 those with a college degree could go on studying at a university level.

Afterwards, the Independent Institute of Economics separated from the Faculty of Engineering started operating in Veszprém in 2001, which was transformed into a Faculty in September 2003. The third great change had an overall impact on the Hungarian educational system including economist training. Our accession to the EU made our accession to the European higher education area also necessary. As a result, in September 2006 the linear training system was introduced, i.e. $\mathrm{BA} / \mathrm{BSc}, \mathrm{MA} / \mathrm{MSc}$ and $\mathrm{PhD}$ trainings were launched.

The two-tier system created by the Bologna process belongs to the most recent chapters of higher education headed by the third, highest level of the doctoral (PhD) training. It was ranked as the $\mathrm{PhD}$ School of Management and Business Administration and also a separate economic science was named. Within the BA/BSc trainings a separate business study course was formed with economic and business study programs distinguished. include

The business study programmes

- applied economics

- business analysis

- public service.

Business trainings include

- human resource management

- economics and management

- commerce and marketing

- international economics

- finance and accounting

- tourism and catering

- business trainer. 
Higher education institutions can launch their bachelor and master study programmes after gaining positive assessment from the Hungarian Accrediting Board (MAB). In this two-tier system there have been more business (economic) study programmes in more than 28 higher education institutions.

To sum up, we can conclude that the economic training has gained its rightful place in the Hungarian higher education. Presumably all legal successors of universities pay attention to boost their reputation and strengthen their relationship with society and also get to know the requirements, expectations and opinions of society.

The history of university level economic training also signals that the institutionalized forms of universities are able to adapt to the economic and social issues according to which changes are permanent

\section{References}

[1] Dürrné Csabina I. - Bochné Tordai I. (1976): Korszerüsítési törekvések az egyetemi közgazdászképzésben. 7. évf. 11. sz. 54-57. p.

[2] Fináczy E. (1899): A gazdasági felsőbb szakoktatás kezdetei Mária Terézia alatt, Magyar Gazdaságtörténeti Szemle, 6. évf. 5. sz. 199-204. p.

[3] Garaj E. (2004): A magyar közgazdászképzés története a kezdetektől az önálló intézménnyé válásig. Letöltés ideje: 2014.03.16.
[4] Győriványi S. (1996): Fejezetek a magyar szakképzés történetéből. Új Pedagógiai Szemle, 46. évf. 10. sz. 94-115. p.

[5] Kahulits L. (1967): A közgazdászképzés és a reform, Gazdaság, 1967. 1. évf. 1. sz. 41-47. $\mathrm{p}$.

[6] Mihalik I. (1995): Küzdelem az önálló egyetemi szintü közgazdászképzésért. In: Tanulmányok a magyarországi közgazdasági felsőoktatás történetéből. Budapest Budapesti Közgazdaságtudományi Egyetem 48-82. p.

[7] Pukánszky B. - Németh A. (1996): Neveléstörténet. Nemzeti Tankönyvkiadó, Budapest. 167

[8] Schack B. - Vincze F. (1930): A kereskedelmi oktatásügy fejlődése és mai állapota Magyarországon. Budapest, Franklin Társulat, 448 p.

[9] Szögi L. - Zsidi V. (1994): Budapesti Közgazdaságtudományi Egyetem. In: Hat évszázad magyar egyetemei és föiskolái, Művelődési és Közoktatási Minisztérium, Budapest, 98 p.

[10] Szögi L. (1995): A közgazdasági képzés Magyarországon a Keleti Kereskedelmi Akadémia alapításáig. In: Tanulmányok a magyarországi közgazdasági felsőoktatás történetéből, Budapest Budapesti Közgazdaságtudományi Egyetem, 5-47. p.

[11]Zsidi V. (1995): A Budapesti Közgazdaságtudományi Kar története 1920-1948. In: Tanulmányok a magyarországi közgazdasági felsőoktatás történetéből. Budapest, Budapesti Közgazdaságtudományi Egyetem 83-98. p.

[12] http://www.kodolanyi.hu/nevelestortenet/? act=menu tart\&rovat mod=archiv\&eid $=2$ 9\&rid=1\&id=91

[13] http://www.felvi.hu

[14] http://www.mab.hu 